\title{
The Common Law and the Law of Nations Under the Federal Constitution *
}

$I^{1}$

$T$ has been asserted that Federal judicial opinion is characterized by what has been termed a "restrictive common-law attitude" toward legislative enactment. This trend to limit statutory innovation upon the common law has from the earliest days of the Supreme Court, invited severe criticism by the ablest of American jurists, laymen and social reformers, of its man-made law overriding the legislative will constitutionally expressed. ${ }^{1}$ While recent decisions of the Supreme Court evidence a willingness to construe statutes in the broad justice of public policies and to take into consideration the economic consequences of a too strict adherence to the rule of stare decisis, there are no signs to be observed, beyond the persistent dissent of a minority of the Court, of any disposition to retreat from the traditional rules and procedure of the common law, always exclusive of legislation creating remedies unknown to the general common law. It would appear that only through amendment of the Constitution are these tendencies to be checked. But, it is submitted, this principle of the restraint of the common law in Federal adjudication has a much greater significance, but little regarded by writers on the American Constitution, and contains within itself the remedy for the too narrow construction it receives, imposing no insuperable barrier to needed social and economic reforms, but in truth ever permissive of the abrogation of its declared rules, or their adaptation and modification to fit the ever advancing understandings of equity and right, its great principles and the ends of liberty kept steadily in view.

The question is one having both a political and an economic aspect and may not be confined to a consideration alone of judicial power under the Constitution. It presents the century-old problem as to the obligation of the common law, under the Constitution, upon all agencies of government, "as a part of the law of the United States in their sovereign character as a nation, and" (note the distinction) "not as a source of jurisdiction, but as a guide and

1 Haines, The Doctrine of Judicial Supremacy, p. 306; Roscoe Pound, The Scope and Purpose of Sociological Jurisprudence, 24 Harvard Law Review, 609; Liberty of Contract, 18 Yale Law Journal, pp. 465, 466.

*Copyright 1921 by J. Whitla Stinson. 
check and expositor in the administration of rights and duties and jurisdiction conferred by the Constitution and laws."'

No subject can be of greater importance in American jurisprudence than whether the common law is in force generally throughout the United States, and whether its rules may be implied from the grant of judicial power in the Constitution. "The whole structure of our present jurisprudence stands upon the original foundations of the common law." 3 The system familiar to the framers of the Constitution was the common law including equity and admiralty. "Whether the common law of England in its broadest sense including equity and admiralty, as well as legal doctrines be the common law of the United States or not, it can hardly be doubted that the Constitution and laws of the United States are predicated upon the existence of the common law."4 Nevertheless the dictum has taken root in authorities on the Constitution of the United States that, "the United States as such can have no common law." The Supreme Court has held in one notable instance that "properly understood no exception can be taken to declarations of this kind .... [if by that is meant] a body of Federal common law separate and distinct from the common law existing in the several states, in the sense that there is a body of statute law, enacted by Congress separate and distinct from the body of statute law enacted by the several states."

The omission of reference to the common law by the Constitution in defining what shall constitute the supreme law of the land is explained by Madison as intended to avoid confusion as to the law obligatory upon the Federal courts and differences in the common law as adopted by the several states." "The conclusion I reach upon this subject," declares Mr. Justice Shiras" "is . . the adoption of the Constitution and the consequent creation of a national government did not abrogate this common law, that the division of governmental powers and duties between national and state governments, provided for in the Constitution, did not deprive the people who formed the Constitution of the benefits of the common law; that as to such matters as were by the Constitution

21 Story on the Constitution $\S 798$.

3 Ibid. \& 157.

4 Story, J. in U. S. v. Coolidge (1813) 1 Gall. 488, 25 Fed. Cas. No. 14,857.

5 Cooley's Principles of Constitutional Law ( $3 \mathrm{~d}$ ed.) p. 149.

Rep. 655.

6 Kansas v. Colorado (1907) 206 U. S. 46, 96, 51 L. Ed. 956, 27 Sup. Ct.

i 5 Writings of James Madison, p. 220.

- Murray v. Chicago \& N. W. Ry. Co. (1894) 62 Fed. $24,41$. 
committed to the control of the national government there were applicable thereto the law of Nations, the maritime law, the principles of equity and the common law".... The broad purpose of the due process clause was declared by Story to be "individual protection and limitation upon power," precluding unbridled authority in the legislature; not such process of law as Congress might, under the proper forms, deem proper to enact, but necessarily consistent with the securities of the common law.

The existence of common law under the Constitution has a historical aspect only slightly considered by authorities upon American constitutional law. A forceable objection to the adoption of the Constitution urged by Colonel Mason of Virginia was that: "there is no declaration of rights and the laws of the general government being paramount to the laws and constitutions of the several states, the ... declaration of rights in the separate states are no security, nor are the people secured even in the enjoyment of the benefits of the common law."10 Madison responded, "this objection surely was not brought forward in the Convention or it would have been placed in such a light that a repetition of it out-of-doors would scarcely have been regarded" ;11 and Hamilton writes, "the truth is that the Constitution is itself, and to every useful purpose a bill or rights." ${ }^{12}$ The first ten amendments to the Constitution, as is well known, originated in this apprehension that the powers granted to the Federal government might give rise to invasions upon those powers reserved to the states, particularly in respect of the protections given by the common law to personal liberties.

The question seems first to arise in respect to the power of the Federal court to invoke a common law jurisdiction having regard to crimes under the law of nations and breaches of the neutrality of the United States. These cases related largely to piracy and the fitting out of privateers. They brought into question the power of the Federal court to punish offenders under the law of nations, sanctioned by the Constitution, and revealed the important fact that the most distinguished jurists of the day, many of whom had been identified with the framing of the Constitution, were in favor of the existence of the jurisdiction asserted. Iredell, Wilson, Rawley, Jay, Peters, Ellsworth, Story and Marshall himself, were among

9 2 Story on the Constitution $\S 1943$.

10 See 2 American Museum, p. 534; 1 Ibid. p. 233.

11 Writings of James Madison, supra, n. 7.

12 The Federalist, No. 84, Ford's Edition. 
these. "The judges of the United States have held generally that the Constitution of the United States was predicated upon an existing common law. Of the soundness of that opinion I have never had a doubt.. I should scarcely go too far were I to say, that stripped of the common law, there would be neither Constitution, nor government. The Constitution is unintelligible without reference to the common law . . . for ten years it has been the doctrine of our Courts that the common law was in force."13 In the Jonathan Robins' case, ${ }^{14}$ contention was made that although the jurisdiction of the courts is extended to all cases of admiralty and maritime jurisdiction, yet if the courts had been created without any express assignment of jurisdiction, they could not have taken cognizance of the causes expressly allotted to them by the Constitution. Marshall retorted that in so far as the case was piracy under the law of nations "it is not admitted that in the case stated the courts could not have taken jurisdiction. The contrary is believed to be the correct opinion." The arguments of these early judges rested in the principal that the establishment of the Federal Government implied the existence of judicial power to preserve it against acts tending to obstruct and prevent the administration of its affairs and the fulfillment of its obligations to foreign powers. The objection that punishment of crimes under unwritten law was ex post. facto and an illegal assumption of legislative power, was urged by Livingston (Louisiana Code), and the bitter attacks of the Democrats (the then Republicans) led to the decisions in United States v. Hudson ${ }^{15}$ and United States v. Coolidge ${ }^{16}$ wherein it was asserted that while certain implied powers must of necessity result to the Federal courts from the nature of their institution, jurisdiction of crimes against the state was not, in the circuit courts of that day, among such implied powers. Wharton, in commenting on the fact that the proceedings in the former case were ex parte and in the latter the Attorney General had abandoned the question, points out that it remains to be determined how far these decisions are in conflict with "Henfield's case."17 It was there held that, though there had been no exercise of the power conferred upon

${ }^{13}$ Speech of Mr. Bayard, of Delaware, in Debates on the Judiciary, in the House of Representatives, 1802.

14 U. S. v. Nash alias Robins (1799) Bee, 266, 27 Fed. Cas. No. 16,175. See generally 2 Beveridge's Life of Marshall, 458 seq.; Oster's Political and Economic Doctrines of Marshall, p. 239.

15 (1812) 11 U. S. (7 Cranch) 32, 3 L. Ed. 259.

10 Supra, n. 4.

17 (1793) Wharton St. Tr. 49, 85, 11 Fed. Cas. No. 6360. 
Congress by the Constitution to define and punish offenses against the law of nations, "the Federal judiciary had jurisdiction of an offense against the law of Nations and may proceed to punish the offender according to the form of the common law." The lamentable consequences of the general abandonment of this jurisdiction have been seen primarily in the sphere of our international relations, in shocking violations of the neutrality of the American government, and in the tardy enactment of espionage legislation whose invasions of common-law securities have been countenanced alone because of the national emergency.

Successive eras have characterized the assertion by the Supreme Court of broad powers to interpret the Constitution. These vicissitudes are traceable not so much to the varying political character of the Court, as to its attitude in respect to its authority under the common law. The exercise of judicial power to read into the Constitution implied authorities and to invalidate legislative acts, was fought from the foundation of the Federal judiciary until the final triumph of Jacksonian democracy, and its aggressions limited until the period of reconstruction after the Civil War, by arguments resting wholly in the strict rules of construction of the common law. The Democrats, constituting the chief enemies of a broad interpretation of judicial power, proclaimed themselves, upon principles of the common law, the protectors of the Constitution from encroachment by the judiciary. This recognition of its obligation upon the courts came from those who had most bitterly resisted the adoption of the Constitution for want of expressed guaranties of common-law rights and who, like Jefferson, had strenuously objected to the doctrine that the common law was in force under the Constitution. "I consider all the encroachments made on that" (the Constitution) "heretofore as nothing compared to the wholesale doctrine that there is a common law in force in the United States of which, and of all cases within its provisions their courts have cognizance." "18 Jefferson admits, however, that Ellsworth, Iredell and Washington himself accepted the larger principle that, as declared by Story, the Constitution appealed to and adopted the common law at least to the extent of making it "the rule in the pursuit of remedial justice in the Courts of the Union."19 Until Story, the last of the great Federalist judges, withdrew from the Supreme Court bench, the common-law rule of 
strict interpretation of legislative enactments in derogation of the common law did not avail to preclude the Court from the widest assertion of implied powers under the Constitution; nor, indeed, did the uniform adherence by these early expounders of the Constitution to the doctrine of the fundamental obligation of the common law, under the Constitution, though not as a source of jurisdiction ${ }^{20}$ work prejudice to individual rights and privileges or the powers of the Government. Rather did they enlarge and fortify them.

The opinion that there is no Federal common law is traceable to an obiter dictum in Wheaton v. Peters. ${ }^{21}$ "It is clear," said Mr. Justice McLean, "there can be no common law of the United States ... . There is no principle which pervades The Union, and has the authority of law which is not embodied in the Constitution and laws of the United States." The court in Lynch v. Clarke, ${ }^{22}$ referring to this statement, distinguishes: "He was speaking of rights of property which are purely questions of State law and regulations," adding, "The Constitution of the United States, like those of all the original states ... . presupposed the existence and authority of the common law. In adopting our State and national constitutions .... our ancestors rejected so much of the common law as was then inapplicable to the situation, and prescribed new rules for their regulation and government. They did not reject the body of the common law. They founded their respective state constitutions and the great national compact upon its existing principles, so far as they were consistent and harmonious with the provisions of those constitutions." "It was not," says Story, "introduced as of original and universal obligation in its utmost latitude; but the limitations contained in the bosom of the common law itself, and indeed constituting a part of the law of nations, were affirmatively settled and recognized in the respective charters of settlement. Thus limited and defined, it has become the guardian of our political and civil rights . . . and by the Goodness of God, we are now enjoying, under its bold and manly principles, the blessing of a free, independent and united government." 23

The present tendency in Federal judicial opinion to hold invalid

20 Duponceau, The Nature and Extent of the Jurisdiction of the Courts of the United States, p. 101.

21 (1834) 33 U. S. (8 Pet.) 591, 8 L. Ed. 1055.

22 (1844) 1 Sandf. Ch. (N. Y.) 583.

231 Story on the Constitution $\S 158$. 
legislation creative of rights, remedies and liabilities, unknown to or unenforceable by the traditional procedure of the common law including equity and admiralty, in support of which position the Supreme Court relies upon the obligation imposed upon Congress, as well as the Federal courts, to effect the fundamental purpose of the Constitution to secure uniformity of law, neither consists with the accommodating spirit of the common law, nor with its true relation to statutory enactment. Story tells us that the nature and the extent of authorities granted by the Constitution and very particularly "the interpretation and exercise of the vested jurisdiction of the courts of the United States must in the absence of positive law be governed exclusively by the common law."2t $\mathrm{He}$ regards the application of common-law renedies, to rights arising under the legislation of states having the rules of common law in view, to be in casibus omissis peremptory upon the courts. The rule from Roman times was to regard enacted law as obligatory in judicial procedure and the common law as filling the gaps, left by enactments and so precluding a failure of justice. ${ }^{25}$ However, "where the statute and common law concur, the conimon law shall be preferred .... the common law is not abolished but is of higher authority."26

Whatever linitations exist upon the grant of judicial power "they must be expressed." No construction of the Constitution may be adopted "unless the words imperiously demand it, which would impute to the framers of that instrument, when granting these powers for the general good, the intention of impeding their exercise." "It would seem impossible," says Story, "to assume if the people intended to introduce a new rule in respect to the decisions of the Supreme Court, and to limit the nature and operations of their judgments in a manner wholly unknown to the common law, and to an existing system of jurisprudence, that some indication of that intention should not be apparent in the Constitution." That the common law should be the instrument of restraints bearing down progressive and enlightened legislation neither accords with its history nor its higher and unwritten sanction. "In matters of civil nature the common law works itself pure by

24 U. S. v. Coolidge, supra, n. 4. Italics ours. 388.

25 Roscoe Pound, Common Law and Legislation, 21 Harvard Law Review.

26 Jameson v. The Regulus (1800) 1 Pet. Adm. 212, 13 Fed. Cas. No. 7, 198.

27 Brewer, $J$. in Kansas v. Colorado, supra, n. 6.

28 Marshall, C. J. in McCulloch v. Maryland (1819) 17 U. S. (4 Wheat.) 316, 408, 4 L. Ed. 579. 
rules drawn from the fountains of Justice - in matters of political nature it works itself pure by rules drawn from the fountain of Freedom." ${ }^{29}$ Consistent alone with these principles the common law remains the ultimate measure of governmental power and private right. In no other way may the broad interpretation of powers conferred on the various departments of government under the Constitution be reconciled, with the authority of the common law. "The accommodating spirit of a system of common law will adjust its improvement to every grade and species of improvement." 30

In so far as the objection of unconstitutionality to legislation rests in its alleged inconsistency with the common law, the inquiry should be whether it operates to take away rights secured by or under the Constitution. If an act of Congress operates to exclude the rightful jurisdiction of the Federal courts, as in admiralty, ${ }^{31}$ it may well be held void in so far as that jurisdiction arises directly from the grant of judicial power in the Constitution. But the mere fact of the inconsistency of rights and remedies with the known processes of the Federal courts would not seem to afford grounds for holding them either irremediable or unconstitutional. Story says, "by common law the framers of the Constitution meant what the Constitution denominated in the third article 'law,' not merely suits which the common law recognized among its old and settled proceedings, but suits in which legal rights were to be ascertained and determined." 32

The growth is apparent through judicial decision of a defined body of Federal common law which may be administered alike by state and Federal courts in all matters not of a character local to a state. This development of Federal common law has been held not to be in conflict with state's rights, and though affecting matters of local state law, it may become generally binding upon state courts. This must have been foreseen by the makers of the Constitution and fulfils sufficiently the demand for uniformity. But that it necessarily operates as a limitation upon the legislative power is very questionable. While authorities admit that the exercise of jurisdiction by the Federal courts is restrained according to certain general principles, some of which arise from the general

29 Wilson, $\mathrm{J}$. in Henfield's Case, supra, n. 17.

30 Ibid.

31 Knickerbocker Ice Co. v. Stewart (1920) 253 U. S. 149, 64 L. Ed. 827 , 40 Sup. Ct. Rep. 444.

:2 Parsons v. Bedford (1830) 28 U. S. (3 Pet.) 433, 7 L. Ed. 732. 
nature of constitutional government and others from rules of comity, the Supreme Court has declared that the grant of judicial power to the Federal courts is unrestricted except in so far as there may be expressed limitations and the apportionment of jurisdiction is acknowledged to be mandatory upon Congress. No part of it may be constitutionally withheld. The existence of a common law in the United States must operate to enlarge and help out the jurisdiction of the Federal courts, not impede its exercise. Mr. Justice Shiras queries" 33 "the courts ... were vested with jurisdiction in admiralty and at common law and in equity. If there is no common law jurisdiction to be exercised and no common law principle to be enforced, why create courts for that purpose?" If the fact that the common law is in force in the United States be denied, a striking anomaly is presented by the inclusion of the English equity system in the Federal judicial system. Likewise the adoption by the Constitution, as the Supreme Court has recently held, ${ }^{34}$ of "approved rules of the general maritime law" leaves small room for doubt that it also brought into the Federal system those rules of the common law consistent with the main objects of the republican form of government it guaranteed to the American people.

Chief Justice Marshall observes: "an Act of Congress ought never to be construed to violate the law of nations, if any other possible construction remains, and consequently, can never be construed to violate neutral rights, or to affect neutral commerce further than is warranted by the law of nations as understood in this country." ${ }^{35}$ The peculiar value of this principle rests in a certain preference enjoined upon the courts of the United States whereby it is sought in construing legislative enactment to avoid intrenchment upon the sphere of obligation asserted under those international sanctions of law known as the laws of nations. The law of nations written or unwritten finds itself in American law a part of the common law. The law of nations is "in part unwritten and in part conventional. To ascertain that which is unwritten we resort to great principles of reason and justice, but as those principles will be differently understood by different nations under different circumstances, we consider them being in some degree fixed and rendered stable by a series of judicial

${ }^{33}$ Murray v. Chicago \& N. W. Ry. Co., supra, n. 8.

34 Knickerbocker Ice Co. v. Stewart. supra, n. 31.

35 The Charming Betsy (1804) 6 U. S. (2 Cranch) 64, 2 L. Ed. 208. 
decisions." ${ }^{38}$ Thus through adjudication, through its unwritten or through its expressed terms, the law of nations under the constitutions of the United States is safeguarded by common law from legislative alteration, if not otherwise, wherever in construing statutes this end can possibly be achieved.

We observe in this line of demarcation between municipal and international law the same restrictive attitude in Federal adjudication which is characterized by maintenance of the rules and principles of the common law. There is a reflection of this rule of construction in Marshall's opinion in Foster v. Neilson. ${ }^{37}$ Nevertheless, "if a treaty operates by its own force and relates to a subject within the power of Congress it can be deemed in that particular only the equivalent of a legislative act to be repealed or modified at the pleasure of Congress." What then of the unwritten law of nations directly sanctioned by the Constitution or itself a part of the common law, appealed to and adopted by the Constitution for the construction and interpretation of its powers and vested jurisdiction? ${ }^{38}$ That such approved rules of the laws of nations enjoy a higher sanction under the Constitution of the United States than ordinary legislative enactments or treaties having no higher validity admits of no doubt. In so far as treaties under the Constitution are declaratory of the law of nations, they have in every sense a supreme obligation which, it is submitted, is comprehensively expressed in the clause "treaties made under the authority of the United States . . . . shall be the supreme law of the land."

The binding force of international compacts implies the extraterritorial authority of municipal law, of the common law. The nexus subsists in law. The reciprocal rights, duties, privileges and immunities flowing to the consenting nations must possess authority as much under "the law of the land" of the high contracting parties as their general acceptance of the law of nations. It presents a sphere of concurrent obligation and mutual national jurisdiction, be it administrative, legislative, or judicial. This is plainly not territorial; it may obviously be maritime, whose law in England "is not the law of a particular country but the general law of nations." ${ }^{39}$ It reaches from the necessities of the case "beyond

${ }^{36}$ Marshall, C. J., in Thirty Hogsheads of Sugar v. Boyle (1815) 13 U. S. (9 Cranch) 191, 198, 3 L. Ed. 701.

37 (1829) 27 U. S. (2 Pet.) 253, 7 L. Ed. 415.

38 See Story, J., in U. S. v. Coolidge, supra, n. 4. Also, supra, n. 19. R. 614 .

39 Lord Mansfield in Luke v. Lyde (1759) 2 Burr. 882, 887, 97 Eng. Rep. 
the seas," to use the parlance of ancient authorities. "No single nation can change the law of the sea . . . that law is of universal obligation and no statute of one or two nations can create obligations for the world. Like all the laws of nations it rests upon the common consent of civilized communities." 40 This restraint must extend to the treaty-making power of the United States in the absence of Constitutional amendment. What is demonstrably true is that through treaty first, through the unwritten and mutually accepted laws of nations, the "law of the land" of one country, in its larger significance, may impose permanent restraints on that of a foreign power with corresponding obligation in the former. This situation compels inquiry how far mere legislative enactment in one country will absolve from international obligation which we have considered under the American system, and what is of equal importance and but slightly regarded, the question whether national law is strictly territorial. "It is only in the absence of any positive rule affirming or denying the operation of foreign laws, courts of justice presume the tacit adoption of them by their own government unless they are repugnant to its interests. It is not the comity of courts, but the comity of the nation which is administered in the same way and guided by the same reason by which all principles of municipal law are guided." " 41 Thus the spirit of the common law in America receives the obligation of foreign law in a friendly correspondence with American legal

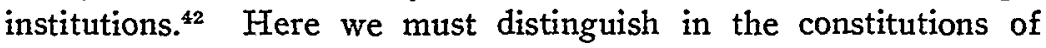
nations, written or unwritten, between their implied or expressed sanction of the common law, its reach, its permissive or its restrictive effect upon international compacts under the law of nations.

Holding that the jurisdiction of the Federal courts over offenses on the high seas is not exclusive of the jurisdiction of consular tribunals, the Supreme Court declares: "The Constitution of the United States can have no operation in another country." 43 If judicial authorities may by proper exercise of the treaty-making power be vested in the officers of the United States residing abroad without derogating from the judicial powers of the Federal courts, it is submitted that governmental power, if not judicial authority,

40 The Scotia (1871) 81 U. S. (14 Wall.) 170, 187, 20 L. Ed. 822.

41 Story on Conflict of Laws $\$ 37$. See also The Armistad (1841) 40 U. S. (15 Pet.) 518, 589, 10 L. Ed. 826; Marshall, C. J. in The Nereide (1815)

13 U. S. (9 Cranch) 388, 422, 3 L. Ed. 769.

+2 Lord Coke in Calvin's Case, 7 Coke 1, 77 Eng. Rep. R. 377.

43 In re Ross (1891) 140 U. S. 453, 35 L.. Ed. 581,11 Sup. Ct. Rep. 897. 
must be coextensive with the laws of nations sanctioned by the Constitution in regulating the extra-territorial rights of citizens of the United States. How then can it be deduced that the Constitution, sanctioning and adopting international law and authorizing international compacts thereunder, can fail of effect in foreign lands whose laws or their obligations it receives upon grounds of comity is not clear, unless it be admitted that in the sense of a social compact, the Constitution of the United States is of no higher obligation than the law of nations and treaties declaratory thereof? Only those laws of nations are void which are repugnant to the paramount authority of the Constitution.

That the Constitution contemplated progressive and ever more just and equitable understandings of international law is patent. If the source of common-law liberties be regarded as derived from unwritten sanctions of the higher law of nature and of territorial obligation solely, and the law of nations be defined as the progressive principles of peaceful, neutral and belligerent right whether on land or on the sea, that the probable assimilation of the latter to the former was the crowning ultimate to be achieved seems probable. We have the common law generally sanctioned by the state constitutions. That the framing of the Federal Constitution was impelled by the desire to give a greater security to the law of nations than afforded by the common law is obvious from contemporaneous comment. "If we examine the constitutions and laws of the several states it is immediately discovered that the law of nations is unprovided with sanction in many cases which deeply affect public dignity and public justice." 44 In conflicts with civil law institutions, the common law is made the rule of decision within the Federal jurisdiction. We have the essential guarantee of the securities of the common law in the Constitution and its amendments. Can it then be said that the Constitution fails to extend its entire force to the protection of these rights in the citizen, be they derived from his state citizenship or impliedly from his allegiance to a power which has forbidden their impairment when the citizen is in foreign lands, subject always to the general law of nations? Must not these considerations be read into every treaty affecting private right whether it have regard solely to the law of nations, or to the power of Congress to regulate commerce and navigation or other intercourse with foreign nations? Is the common law under the Constitution, admitting its general adher-

11 Secret Proceedings of the Constitutional Convention, p. 194. 
ence with the law of nations, of less obligation abroad than at home? Certainly not as understood in England since Magna Charta, nor indeed before. As a canon of construction, the common law governs the Constitution.

We see then a concurrence within the sphere of the treatymaking power of the United States between the securities flowing to citizens of this country and their rights abroad and those of the subjects of Great Britain. In England the common law remains the measure of administrative power. Its restrictions repel prerogatives invading the assurances of the unwritten British constitution. If not coextensive these latter are at least closely parallel with those secured under the Federal Constitution restraining in turn the powers confided to the several branches of the American government. All compacts between Great Britain and the United States must refer themselves to these wholly municipal regulations, not alone de l'ordre interne, but of the common law itself. The common assurances of the kingdom are synonymous with the spirit of the Constitution of the United States. "The truth is ... that the Constitution is, itself, in every rational sense, and to every useful purpose, a bill of rights. The several bills of rights in Great Britain form its constitution, and conversely the bill of rights of each state is its bill of rights. And the proposed Constitution if adopted will be the bill of rights of the Union." 45

This indissoluble bond of law forms the foundation of every treaty between America and Great Britain. It enters into the substance of their national compacts; first, in its effect upon the rights of the individual, and again in respect to the exercise of sovereign power, finally in the subserviency of the laws of nations to its fundamental institutions. "The law of nations is obligatory in the same manner as the law of nature is obligatory on individuals. (Men) cannot (by forming themselves into political units) by this union discharge themselves from any duties they previously owed to those who formed a part of the political association. To this universal society it is a duty that each nation should contribute to the welfare, the perfection and the happiness of others." 46

These considerations dominate the jurisdiction of any international tribunal into which the United States and Great Britain may enter. The restraint of the common law must dominate their international commitments. To deny this would be to deny the

${ }^{45}$ Hamilton, The Federalist, No. 84, Lodge's Edition.

16 Wilson, $J$. in Henfield's Case, supra n. 17. 
corner-stone of all juristic thought in America and England, to rend asunder the concord upon which their separate sovereignties rest. We hear much in these days as to the jurisdictional power of such a tribunal over non-justiciable controversies, cases of conflicting national policies, be they colonial or affecting regional understandings, or again unilateral and touching national securities; the ever-impending menaces of war. One principle common to America and to England solves these difficulties. It is the common law, of which an early American jurist writes: "These maxims of national law, through the sacred precepts of nature, and of nature's God, have been too often unknown and unacknowledged by nations. Even where they have been known and acknowledged their calm still voice has been drowned by the clamors of ambition and by the thunder of war." ${ }^{47}$ This stone will not be rejected by the builders of today. It is a principle big with possibilities in international accords. It is the standard which America raises to the nations. This "inestimable inheritance" which followed our fathers to these shores is to become the one law of nations. "This sacred law prohibits one state from exciting disturbances in another, from depriving it of its natural advantages and from calumniating its reputation, from seducing citizens, from debauching the attachment of its allies, from fomenting and encouraging the hatred of its enemies." 48 It is the sole basis of an association of nations, the cement of Anglo-American civilization.

J. Whitla Stinson.

Metropolitan Club,

New York City.

17 Ibid. See also 1 Wilson's Works (Andrew's edition) p. 153.

48 W'ilson. J., charge to Grand Jury in Henficld's Case, supra. n. 17. 